\title{
To Buy or Not to Buy? The Changing Relationship between Manhattan Rents and Home Prices
}

\author{
Jason Bram
}

\begin{abstract}
Much of the nation has experienced steep declines in housing prices in recent years. In Manhattan, however, apartment sales prices did not fall as sharply. A study of price-rent ratios in the New York City borough concludes that, while apartment rents are driven by supply and demand forces, apartment sales prices are driven in part by speculative factors, and they sometimes rise or fall to levels incommensurate with prevailing rents. Manhattan price-rent ratios, although off their 2008 highs, are still up dramatically over the past two decades, suggesting less financial "value" today in an apartment purchase there.
\end{abstract}

$\mathrm{T}$ he past decade's volatility in housing prices across much of the nation has increased the need for a better understanding of the determinants of home prices. Indeed, many recent studies have focused on the relationship between prices and economic fundamentals - most notably, excess housing supply, household income (affordability), and/or market rents. ${ }^{1}$ Residential rent is a particularly effective tool for analyzing whether home prices are supported by fundamentals, in much the same way that corporate profits are useful for valuing stocks. Yet the main shortcoming of this type of analysis is that in most of the United States, rental units and owner-occupied homes differ substantially in quality and, thus, value. ${ }^{2}$ In New York City's borough of Manhattan, however, a lack of comparability poses less of a problem, because there is a large luxury rental market and renters and owners often live side by side.

In this edition of Second District Highlights, we examine trends in residential rents and home (that is, apartment) purchase prices in Manhattan. We focus on the ratio of prices to rents as a way to gauge the financial "value" of a home purchase. The ratio has risen dramatically over the past two decades, suggesting that there is less value today in a home purchase. We study the ratio using a simplified framework of the relationship between housing (asset) prices and rents. In effect, we consider the fundamental principle that monthly rent is determined by market conditions, while the price of a housing unit is based on the expected stream of rent (income) generated by that asset minus associated costs. We conclude that apartment rents in Manhattan tend to be driven by market forces - that is, supply and demand. By comparison,

\footnotetext{
${ }^{1}$ Well before the peak in national home prices, Case and Shiller (2003) examined the relationship between prices and income measures, as well as other economic measures, across states and over time; they concluded that prices were higher than warranted in some areas and would likely fall. Glaeser, Gyourko, and Saks (2005a) analyzed the role of supply-side factors, including regulation, in boosting home pricesparticularly in densely populated areas.

2 According to Glaeser and Gyourko (2009), marked differences between the rental and purchase markets make it difficult to examine the relationship between prices and rents using a financial framework.
} 
apartment (co-op and condominium) sales prices, though also largely a function of supply and demand, are driven in part by speculative factors and sometimes rise or fall to levels incommensurate with prevailing rent levels.

\section{A Framework for Analyzing the Price-Rent Relationship} A widely used metric to gauge home values is the price-rent ratio. For an individual home, the ratio reflects the residence's market price divided by the annual market rent it would generate. When price-rent ratios are calculated, they generally represent averages for a particular geographic area, usually a metro area or county. A high ratio suggests that house prices are overvalued, while a low one suggests undervaluation. However, other variables affect the fundamental relationship between prices and rents-namely, interest rates and, to a lesser degree, other costs, such as property taxes, insurance expenses, and maintenance fees.

To understand this relationship, consider how a prospective buyer or tenant would choose between purchasing a particular apartment and renting a comparable unit. Most people view this decision in terms of monthly cash flow: How much money is spent each month to live in the residence when renting compared with buying? This is the framework that real estate professionals and prospective buyers frequently use when discussing finances, especially when an individual is deciding whether to make the plunge from renting to buying.

However, this type of basic cash flow analysis has flaws. First, the paying down of principal on one's mortgage is not an expense per se, and the amount should not be included with mortgage interest payments, property taxes, or monthly maintenance fees. The paying down of principal merely represents asset accumulation. Second, for any given purchase price and mortgage rate, the monthly payment will vary depending on the loan-to-value ratio - that is, it will be affected by the size of the down payment. For instance, a sufficiently large down payment would give a buyer a relatively low monthly cash flow, even with a very high purchase price. In the extreme case of a 100 percent down payment, the buyer's monthly outlay in terms of cash flow would be unaffected by the purchase price and would vastly understate the true monthly cost. Another flaw of this type of cash flow analysis is that it must factor in other owner costs implicitly included in one's rent. Costs include property taxes, repair and maintenance, and especially monthly co-op and condo fees - which can be particularly high in New York City. Therefore, even if two co-op or condo units have the same purchase price, one might be considerably more expensive on a monthly basis, simply because its monthly fees are higher. Finally, income tax implications associated with the deductibility of mortgage interest and property taxes must be considered, although the implications vary depending on the purchaser's financial circumstances.

A more accurate way to estimate the relationship between prices and rents is to tally up the monthly costs associated with the purchase. Costs include maintenance fees (for a co-op), common charges and property taxes (for a condo), upkeep costs for the unit that are included in a tenant's rent, and mortgage interest. One would also want to estimate the monthly mortgage interest amount based on the full purchase price, rather than on just the amount borrowed — that is, the owner costs assuming that the purchase was made with no down payment. This action effectively "levels the playing field" between buying and renting, because renters are not constrained by the need to make a down payment. In effect, it assumes that the expected return on money that might be used as a down payment (the opportunity cost) equals the mortgage interest rate.

To more formally assess the changing relationship between rents and purchase prices, we establish a framework to identify how relevant factors, such as mortgage rates and tax rates, fit in. Based on a simplified model of home prices and rents, rent should cover the user cost of housing. In effect, factors that should cause prices to rise relative to rents include:

- lower interest rates,

- lower effective property tax rates,

- higher federal tax rates (leading to a higher value of mortgage interest deduction), and

- lower maintenance/depreciation rates (monthly operating costs).

In addition, expectations play a role in elevating prices relative to rents, specifically those associated with risk-adjusted expected capital gains. ${ }^{3}$ (Box 1 describes the price-rent relationship in more detail.)

\section{The Manhattan Housing Market}

We now apply our price-rent framework to interpreting trends in Manhattan's apartment sales and rental markets over the past two decades and in the current market. New York City has one of the highest priced housing markets in the United States, reflecting extraordinarily high land values. Various forces contribute to high land values. The combination of a limited supply of land-especially on the island of Manhattan - and robust demand by the business and household sectors helps explain why a Manhattan apartment tends to sell for a multiple of a comparably sized unit's price in most other major U.S. cities. The primary reason for the high demand is twofold: A wealth of amenities motivates many people to live in Manhattan, and agglomeration economies make it profitable for many types of business to locate there. ${ }^{4}$

\footnotetext{
${ }^{3}$ This reflects the rate at which the home value is expected to appreciate over time minus a risk premium. Alternatively, it can be thought of as the rate of return on a risk-free investment that would make someone indifferent between such an investment and investment in the home.

${ }^{4}$ Supply factors are also present. Glaeser, Gyourko, and Saks (2005b) attribute some of Manhattan's high housing costs-both prices and rents - to supply constraints and regulatory issues.
} 
Box 1

\section{The Price-Rent Relationship}

A price-rent relationship can be described by a simplified "user cost of housing" framework as follows: $P_{t} / R_{t}=1 /\left[\left(i_{t}+T^{P}{ }_{t}\right) /\left(1-T_{t}{ }_{t}\right)+\right.$ $\left.M_{t}-E_{t} G_{t+1}\right]$, where $R$ is the annual rent, $P$ is the price, $i$ is the real interest (mortgage) rate, $T^{P}$ is the property tax rate, $T^{I}$ is the income tax rate, $M$ is the annual maintenance and depreciation rate, and $E_{t} G_{t+1}$ is the risk-adjusted expected capital gain (appreciation) one year ahead. ${ }^{\text {a }}$ The transaction costs associated with an apartment purchase, which can be formidable in New York City, can be viewed as part of (incremental to) the price, and can be added on. (Thus, price data tend to understate the true cost of a home purchase as well as the price-rent ratio, although the degree of understatement should remain fairly constant over time.)

Because the first three factors in the framework are measurable, the price-rent relationship is often used to infer or "back out" the expected capital gain. However, the expected capital gain tends to amplify cycles in the housing market. The reason is that this factor is based on subjective expectations and can be driven by recent trends in housing prices. When prices go up rapidly (relative to rents), people's expectations may change in the same direction: They expect future appreciation to be more rapid and they increasingly see a home purchase as less risky. ${ }^{\text {b }}$

a Our "user cost of housing" framework is described in https://www .economy.com/home/products/samples/case-shiller-methodology.pdf. A more detailed analysis of house price valuation techniques can be found at http://www.bls.gov/ore/pdf/ec100090.pdf.

b There can also be perceived risks to not buying. Sinai and Souleles (2005) find that "rent risk" - the risk that market rents may rise substantially—is a factor determining an individual's decision whether to purchase or rent, and it can affect the price-rent ratio moderately.

To offer insight into local real estate dynamics, we describe some basic facts and unique characteristics of Manhattan housing. First, almost all housing units are in multi-family structures, and a large majority are renter-occupied. Second, a large proportion of rental units are rent-stabilized, with tenants generally paying below-market rents. Thus, a conventional analysis comparing prices with rents across all housing units would lead to a distorted view of the underlying relationship between the two markets. ${ }^{5}$ Third, in New York - in contrast to other areas in the nation-co-ops account for a larger share of owner-occupied units than condos do. Co-ops tend to have stricter rules about owners renting their units - particularly for an extended period of time - and typically have underlying mortgages, which can distort valuations.

\section{Trends in Prices and Rents}

Consistent and reliable data on prices and especially rents over time are not easy to come by. Recall that a sizable number of

\footnotetext{
${ }^{5}$ According to the U.S. Census Bureau's 2005-09 American Community Surveys, the median price of an owner-occupied home in Manhattan $(\$ 800,000)$ would be
}

\section{Chart 1 \\ Median Price Compared with Average Monthly Rent on Manhattan One-Bedroom Apartments}

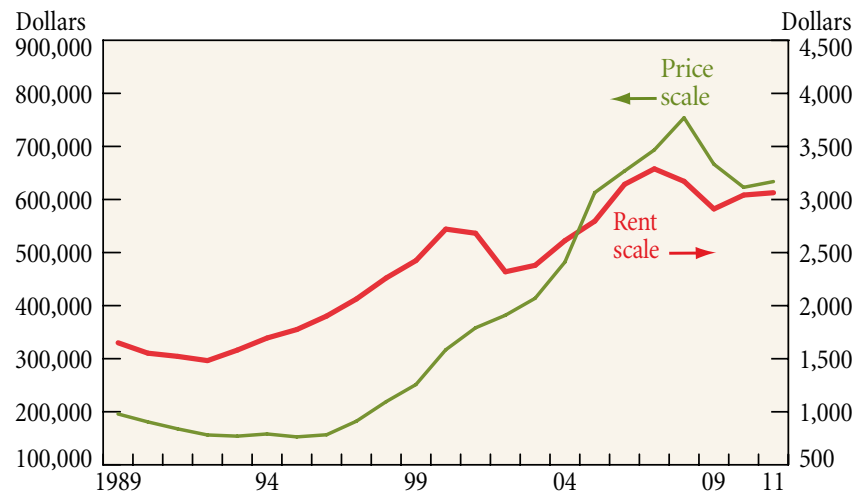

Sources: Miller Samuel (prices); Nancy Packes Real Estate (rent).

Note: Price refers to the median price of one-bedroom co-ops and condominiums; rent refers to average monthly rent on new leases.

Manhattan renters occupy rent-regulated units and pay belowmarket rents. Thus, official data on prevailing or average rents understate the market rents paid by new tenants. To conduct our analysis, we therefore use transaction-based rent data from a long-standing residential real estate firm. The data are based on newly leased units and are broken out by apartment size (for example, studio, one-bedroom); they also include relatively few rent-stabilized apartments and are weighted more toward luxurious units, which tend to be more comparable with co-ops and condos. Similarly, the co-op and condo sales price data we use are based on transactions, compiled from a variety of sources by a residential appraisal firm. ${ }^{6}$

To illustrate trends in Manhattan prices and rents over the past two decades, we present prices and rents for one-bedroom apartments from 1989 to 2011 (Chart 1). ${ }^{7}$ While prices and rents have risen considerably over this period, prices have increased much more dramatically—a result that also holds for studio apartments and particularly two-bedroom units.

Our data begin at the tail end of the 1980s housing boom. During New York City's severe 1989-93 downturn, rents declined only modestly, falling 5 to 10 percent, whereas co-op and condo prices dropped nearly 25 percent. As the economy began to pick up in 1993, so did the rental market—from then until 1999,

\section{Footnote 5 continued}

more than fifty-five times the median annual rent there $(\$ 14,472)$; these figures constitute a ratio considerably higher than the one suggested by our analysis.

${ }^{6}$ Rent data are from Nancy Packes Inc. (formerly Feathered Nest); sales data are from appraisal firm Miller Samuel Inc. All data are annual averages.

${ }^{7}$ Rent figures represent average rent, which is the only summary measure available. Purchase figures are median transaction prices. Average price data are also available, but they tend to be more volatile and are less comparable with rents because of a more skewed distribution. 
rents rose at an average rate of about 7 to 8 percent per year, accelerating to a double-digit pace in 2000. In contrast, apartment prices lagged during the initial stage of the expansion, remaining essentially flat until 1996 . This was when price-rent ratios bottomed out for one- and two-bedroom apartments and neared the bottom for studio units (Chart 2).

In the latter part of the 1990s, as the economic expansion strengthened, home prices accelerated sharply and rose at a doubledigit pace - far surpassing the growth in rents—and the price-rent ratio increased. Prices continued to rise relative to rents in the city's 2001-03 downturn and through most of the subsequent expansion. In 2008, rents turned downward as the economy slowed, but prices continued to climb, which pushed price-rent ratios to record highs. ${ }^{8}$ Since 2008, the ratios have retreated from their highs, as rents have fallen less sharply than prices did in 2009 and have rebounded by more. Despite this pullback, price-rent ratios in Manhattan remain more than twice as high as they were in the mid-1990s.

We examine these cycles and trends over the past twenty-three years, and emphasize some key points about prices and rents in Manhattan. First, as the above discussion demonstrates, rents tend to respond fairly quickly to economic cycles, while price movements tend to lag rents by one to two years. This pattern is consistent with the view that rents are based more on market fundamentals, while prices reflect more speculative and psychological factors. Prices are also less prone to fluctuating in response to forces viewed as temporary. Thus, prices tend to respond more slowly to fundamentals than do rents; when the two diverge, prices are more likely to converge back toward rents than the reverse. ${ }^{9}$ Second, price-to-rent ratios tend to be consistently higher for larger apartments than for smaller units (Chart 2). This may be due in part to the greater similarity between rentals and co-ops/condos among smaller apartments than among larger units. ${ }^{10}$ Third, and most noteworthy, between 1996 and 2008, average rents rose 60 to 70 percent, whereas selling prices more than tripled. Thus, price-to-rent ratios more than doubled over this period, and nearly tripled for twobedroom apartments.

Until a few years ago, all of the factors that influence the equilibrium price-rent ratio were likely helping to elevate prices relative to rents. This still appears to be true for mortgage rates, which have recently declined to historically low levels. However, the trend in effective property tax rates has evidently reversed. Interestingly, the effective property tax rate generally amplifies cycles in New York City because of the way these taxes are

\footnotetext{
8 Reported selling prices in 2008 and 2009 were likely overstated somewhat because of a pronounced shift in the mix of sales toward new luxury condos, according to an appraisal firm that tracks prices. However, reported rents for those years were also likely overstated, as many new leases included concessions (such as one to two months of free rent) that offset much of the effect on price-rent ratios.

9 This result is consistent with findings from a nationwide analysis in Gallin (2004).

10 It may also be due to the fact that studio sales transactions are more likely to be for co-ops (rather than condos) than are sales of larger units; condos tend to be more expensive because there is no underlying mortgage.
}

Chart 2

\section{Manhattan Price-Rent Ratio by Apartment Size}

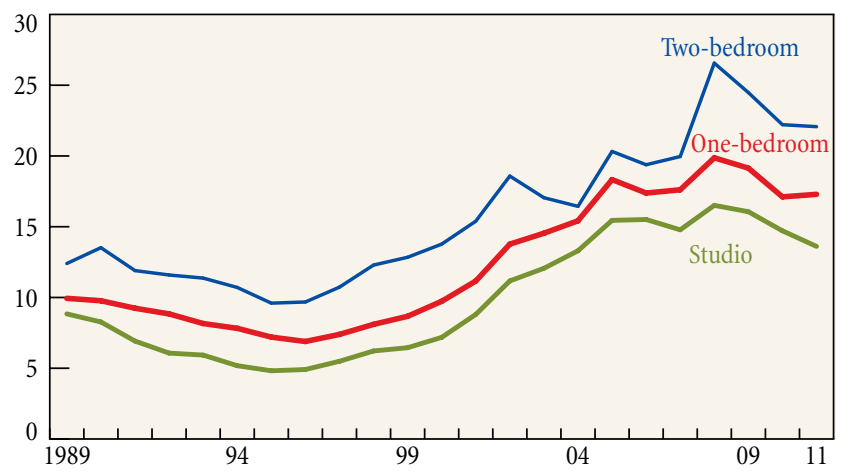

Sources: Miller Samuel (prices); Nancy Packes Real Estate (rent); Federal Reserve Bank of New York calculations.

Note: The ratio represents the median price of a co-op/condominium divided by the average annual rent (monthly contract rent on new leases $\mathrm{x} 12$ ).

assessed. Annual increases in property assessments are capped; so, when prices are rising briskly, the effective property tax rate is usually low and declining, since it is based mainly on belowmarket property values. The declining property tax burden tends to put additional upward pressure on prices. By the same token, when prices are falling, the effective tax rate typically rises because assessed values are still catching up with current market values; this puts further downward pressure on prices.

\section{How High Is "Too High"?}

Given that the relationship between prices and rents was relatively stable through much of the 1990s, one might surmise that the low price-rent ratio during that period represented the norm, and that the ratio should inevitably revert to that level. Such a move would imply that Manhattan co-op and condo prices are roughly twice as high as warranted by economic fundamentals. However, there is no basis for assuming that price-rent ratios in the mid-1990s were "correct" or represented any kind of long-term equilibrium. In fact, there is some reason to believe that those levels may have been too low. For example, even in 1989, price-rent ratios were 30 to 40 percent higher than they were in the mid-1990s. Moreover, at least some of the surge in the ratio since the mid-1990s can be attributed to marked declines in mortgage interest rates over this period. ${ }^{11}$ Some of the increase also evidently reflects declining effective property tax rates. ${ }^{12}$

\footnotetext{
11 Himmelberg, Mayer, and Sinai (2005), who look at trends in local home prices and rents in forty-six metro areas over twenty-five years, find that the degree to which prices rose relative to rents is explained largely by low interest rates. By 2011, thirty-year mortgage rates, which were roughly 8 percent in the mid-1990s, had fallen to well under 5 percent. However, Haughwout et al. (2011) find that tighter credit in recent years has had the opposite effect, offsetting some of the influence of lower mortgage rates.

12 The New York City Independent Budget Office estimates that the average effective property tax rate fell from 1.7 percent in 1996 to 0.8 percent in 2008 ; the effective rate has likely risen somewhat through 2011.
} 


\section{Illustrative Exercise: Imputed and Actual Prices and Ratios for a One-Bedroom Manhattan Apartment 2011 and 1996}

\begin{tabular}{|c|c|c|c|c|c|c|}
\hline \multirow[b]{2}{*}{ Assumption } & \multicolumn{3}{|c|}{2011} & \multicolumn{3}{|c|}{1996} \\
\hline & Scenario 1 & Scenario 2 & Scenario 3 & Scenario 1 & Scenario 2 & Scenario 3 \\
\hline Expected annual price change & No increase & 4 percent increase & 4 percent increase & No increase & 4 percent increase & 4 percent increase \\
\hline Maintenance plus depreciation cost & 2.5 percent of price & 2.5 percent of price & 2.0 percent of price & 2.5 percent of price & 2.5 percent of price & 2.0 percent of price \\
\hline Monthly rent & $\$ 3,055$ & $\$ 3,055$ & $\$ 3,055$ & $\$ 1,893$ & $\$ 1,893$ & $\$ 1,893$ \\
\hline Mortgage rate (percent) & 4.5 & 4.5 & 4.5 & 7.8 & 7.8 & 7.8 \\
\hline Property tax (percent) & 1.0 & 1.0 & 1.0 & 1.7 & 1.7 & 1.7 \\
\hline Imputed price & $\$ 344,249$ & $\$ 551,340$ & $\$ 596,170$ & $\$ 135,951$ & $\$ 178,740$ & $\$ 186,060$ \\
\hline Actual price & $\$ 633,750$ & $\$ 633,750$ & $\$ 633,750$ & $\$ 156,625$ & $\$ 156,625$ & $\$ 156,625$ \\
\hline Imputed ratio & 9.4 & 15.0 & 16.3 & 6.0 & 7.9 & 8.2 \\
\hline Actual ratio & 17.3 & 17.3 & 17.3 & 6.9 & 6.9 & 6.9 \\
\hline
\end{tabular}

Sources: Nancy Packes Real Estate (rent); Board of Governors of the Federal Reserve System/Haver Analytics (mortgage rate); Federal Reserve Bank of New York estimate, based on data from the New York City Independent Budget Office (property tax); Miller Samuel (actual price); author's calculations.

In addition to assessing changes in this ratio over time, we can gauge an "appropriate" level for the ratio-based on our user cost of housing equation - by looking at other factors affecting the relationship between prices and rents. As the equation suggests, it is possible to estimate a price, based not only on rent but also on other pertinent factors - specifically, the mortgage rate, the effective property tax rate, income tax rates, and the annual cost of maintenance and depreciation. In effect, this estimation enables us to determine the extent to which prices and rents are misaligned. ${ }^{13}$ (Box 2 looks at how Manhattan and the New York City area compare with other areas in terms of the price-rent relationship.)

To illustrate this scenario, we present rent, price, and other relevant data for a one-bedroom Manhattan apartment according to various assumptions (see table). The table's first columnwhich assumes no expected price appreciation, 2.5 percent annual maintenance and depreciation, ${ }^{14}$ and a reported monthly rent of \$3,055 in 2011 — shows that the imputed price would be nearly $\$ 350,000$ and the expected ratio would be 9.4 -roughly half the actual levels. ${ }^{15}$ However, if one assumes that prices are expected to rise 4 percent per year (column 2), the imputed price for that same one-bedroom apartment jumps to about $\$ 550,000$ and the imputed price-rent ratio becomes 15-still somewhat below the actual ratio of 17.3, but not dramatically so. If one then assumes a somewhat lower maintenance and depreciation cost of

\footnotetext{
${ }^{13}$ Gallin (2004) looks at the ratio of rents to prices at the national level, and finds that periods in which house prices are high relative to rents appear to be followed by periods in which prices adjust downward (relative to trend) to a greater degree than do rents adjusting upward.

14 The maintenance and depreciation estimate is rough and highly variable. Using standard MACRS (modified accelerated cost recovery system) accounting techniques, we assume that real estate structures depreciate 3.6 percent per year; assuming that the structure accounts for a third of the total value of a typical Manhattan apartment, the cost of depreciation would be 1.2 percent. Additional maintenance costs would include expenses typically covered by rent: water and sewer charges, fuel costs, insurance costs, and building staff costs.

15 These estimated gaps may be somewhat understated because the actual prices do not include transaction costs (which often tack on 4 to 5 percent to the measured price), whereas the estimated prices implicitly include such costs.
}

\section{Box 2 \\ How Do Price-Rent Ratios in Manhattan and Other Areas Compare?}

Recall that a caveat in our attempt to estimate the equilibrium level of apartment prices involves the issue of comparability - that is, the degree to which summary rent measures and summary price measures pertain to comparable units. While this disparity appears to pose less of a problem in Manhattan than elsewhere, it should not be ignored completely. If the typical co-op or condo transaction is for a considerably more desirable or luxurious apartment than the typical rental transaction represents, the gap between actual and predicted prices could be exaggerated.

A 2010 study by a real estate blog addressed the comparability issue by using estimated price-rent ratios for individual housing units in major areas to approximate median price-rent ratios for each of the areas. The ratios ranged from 17.8 in metropolitan New York Cityroughly in line with our estimates for Manhattan-to 7.5 in Miami-Fort Lauderdale. ${ }^{a}$ These figures suggest that price-rent ratios are high in New York City, not only when compared with earlier years but also when compared with other metro areas. Moreover, they imply that comparability is not substantially distorting the ratio for Manhattan.

a Source: Zillow Real Estate Research Blog, http://www.zillow.com/blog/ research/2010/09/21/a-better-price-rent-ratio/.

2.0 percent (column 3), the imputed ratio is a little more than 16. Using parallel analysis for 1996 - when the ratio was at its low - we see that the average monthly rent was $\$ 1,893$, the mortgage rate was 7.8 percent, and the effective property tax rate was estimated at 1.7 percent. If we again use 2.5 percent as the combined maintenance and depreciation rate, the predicted price would be $\$ 136,000$ and the expected ratio would be about 6 . This price is 13 percent below the actual median price of $\$ 156,625$ for a one-bedroom apartment in 1996, and the corresponding ratio is 6.9. However, if one assumes expected price appreciation of 
4 percent, the predicted (imputed) price rises to $\$ 180,000$ and the ratio climbs to nearly 8 - well above the actual ratio-suggesting that prices would have been undervalued in 1996. An important aspect of this exercise is that it illustrates how markedly not only mortgage rates but also expectations can drive the estimation of an "appropriate" price-rent ratio.

\section{Conclusion}

Apartment prices in Manhattan have increased substantially relative to rents over the past seventeen years, raising concern about the sustainability of current prices. Although they have retreated somewhat since 2008, price-rent ratios in the borough are more than twice as high as they were in the mid-1990s. Part of this increase can be explained by lower mortgage rates, which tend to lift sales prices relative to rents by reducing financing costs, and by lower property taxes. Moreover, price-rent ratios appear to have been unusually low in the mid-1990s. Still, current rent levels, mortgage rates, and property tax rates make it difficult to account for the high prices of Manhattan co-ops and condominiums in 2011 without assuming an expected future price appreciation of at least 4 percent per year. That figure could be even higher if transaction costs and risk premiums are included. While the analysis here covers the period through 2011, reports of accelerating rents but stable apartment prices in 2012 suggest that people may have tempered their expectations for price appreciation.

\section{References}

Case, Karl E., and Robert J. Shiller. 2003."Is There a Bubble in the Housing Market?" Brookings Papers on Economic Activity, no. 2: 299-342.

Gallin, Josh. 2004."The Long-Run Relationship between House Prices and Rents." Board of Governors of the Federal Reserve System, Finance and Economics Discussion Series, no. 2004-50, September.

Glaeser, Edward L., and Joseph Gyourko. 2009. "Arbitrage in Housing." In Edward L. Glaeser and John M. Quigley, eds., Housing and the Built Environment: Access, Finance, Policy. Cambridge, Mass.: Lincoln Institute of Land Policy.

Glaeser, Edward L., Joseph Gyourko, and Raven E. Saks. 2005a. "Why Have Housing Prices Gone Up?” American Economic Review 95, no. 2 (May): 329-33. .2005b. "Why Is Manhattan So Expensive? Regulation and the Rise in House Prices." Journal of Law and Economics 48, no. 2 (October): 331-70.

Haughwout, Andrew, Donghoon Lee, Joseph Tracy, and Wilbert van der Klaauw. 2011. "Real Estate Investors, the Leverage Cycle, and the Housing Market Crisis." Federal Reserve Bank of New York Staff Reports, no. 514, September.

Himmelberg, Charles, Christopher Mayer, and Todd Sinai. 2005. “Assessing High House Prices: Bubbles, Fundamentals, and Misperceptions.” Journal of Economic Perspectives 19, no. 4 (Fall): 67-92.

Sinai, Todd, and Nicholas S. Souleles. 2005. "Owner-Occupied Housing as a Hedge against Rent Risk.” Quarterly Journal of Economics 120, no. 2 (May): 763-89.

\section{ABOUT THE AUTHOR}

Jason Bram is a senior economist in the Research and Statistics Group of the Federal Reserve Bank of New York.

Current Issues in Economics and Finance is published by the Research and Statistics Group of the Federal Reserve Bank of New York. Linda Goldberg and Thomas Klitgaard are the editors.

The content co-editor of this article is Giorgio Topa.

Editorial Staff: Valerie LaPorte, Mike De Mott, Michelle Bailer, Karen Carter, Anna Snider

Production: Jessica lannuzzi, David Rosenberg, Jane Urry

Back issues of Current Issues are available at http://www.newyorkfed.org/research/current_issues/.

The views expressed in this article are those of the author and do not necessarily reflect the position of the Federal Reserve Bank of New York or the Federal Reserve System. 


\section{Follow Us on Twitter!}

The Research Group has launched a Twitter feed, designed to offer the first word on developments in the Group, such as:

- new publications and blog posts,

- updates on economists' work and speaking engagements,

- postings of key indexes and data,

- media coverage of the Group's work, and

- other news of interest to website visitors.

\section{Follow us: @NYFedResearch}

\section{RELATED READINGS FROM THE FEDERAL RESERVE BANK OF NEW YORK'S RESEARCH GROUP}

\section{Liberty Street Economics Blog Posts}

Available at http://libertystreeteconomics.newyorkfed.org/

Good News or Bad on New York City Jobs?

Jason Bram and James Orr

August 13, 2012

Is Wall Street the Only Street in New York City?

Jason Bram, Jonathan Hastings, and James Orr

June 6, 2012

New York City's Economic Recovery—Main Street Gets the Jump on Wall Street

Jason Bram and James Orr

May 2, 2011

\section{Second District Highlights Articles}

Available at http://www.newyorkfed.org/research/current _issues/second_district.html

The Price of Land in the New York Metropolitan Area

Andrew Haughwout, James Orr, and David Bedoll

Second District Highlights, vol. 14, no. 3, 2008

The price of vacant land in an urban area is a fundamental indicator of an area's attractiveness. However, because the value of vacant land is hard to measure, indirect methods are typically used to gauge prices. A more direct approach to measuring land prices, using a unique data set, reveals that the price of unimproved land in the New York area is high, and rose sharply from 1999 to 2006. The rising trend suggests the underlying strength of the area's economy and the increasing value of the area's productivity and amenities. 